\title{
International Higher Education and the Mobility of UK Students
}

\section{Rachel Brooks and Johanna Waters}

Published in the Journal of Research in International Education, 2009

\author{
Dr. Rachel Brooks \\ Department of Political, International and Policy Studies \\ University of Surrey \\ Guildford \\ GU2 7XH \\ r.brooks@surrey.ac.uk \\ Dr. Johanna Waters \\ Department of Geography \\ Roxby Building \\ University of Liverpool \\ Liverpool \\ L69 7ZT \\ j.l.waters@liverpool.ac.uk
}

\section{Acknowledgements}

This research was funded by the British Academy Larger Research Grants Scheme (20072008). The authors would like sincerely to thank Helena Wilson for her help with the collection of data and Sandra Mather, at the University of Liverpool, who created the maps used here. We would also like to thank the 85 respondents who were interviewed as part of the project, and participants at workshop on Student Mobilities held at the University of Surrey $\left(24^{\text {th }}\right.$ June, 2008) for their feedback on this project. 


\title{
International Higher Education and the Mobility of UK Students
}

\begin{abstract}
In the context of increasing academic interest in the internationalisation of education and the international mobility of students, this paper draws on findings of a recent research project examining students from the UK as they seek higher education overseas and subsequent employment. The discussion is framed around four key themes (the importance of 'second chances'; 'global circuits of HE’; ‘experiences of travel' and 'labour market outcomes'), which address the motivations and experiences of 85 individuals who are seriously considering or have recently obtained an international higher degree. [87 words]
\end{abstract} Key Words: International education; higher education; UK students; mobility

\section{Introduction}

This paper draws on findings of a recent research project examining the international mobility of students from the UK as they seek higher education overseas and subsequent employment. To date, most of the interest in international student mobility has focussed on young people moving from countries in East and Southeast Asia to the major studentreceiving destinations in North America, Canada, Australia, New Zealand or the UK (Butcher, 2004; Collins, 2006; Lewis, 2005; Waters, 2005, 2006).Whilst these students are thought to seek valuable 'cultural capital' attached to an English-speaking, Western education 
(Waters, 2006), the motivations for UK students who go abroad for their education are less clear. Existing research on the international mobility of UK students has focused on temporary mobility within a degree programme, for a period of between 6 and 12 months, and is concerned primarily with student migration to Europe (Findlay et al., 2006; King and Ruiz-Gelices, 2003). Our project differs in that it examines mobility for the whole of an undergraduate or postgraduate degree; it considers the range of potential destination countries, limited only by the restrictions of the sample; and it also explores the impact of mobility on subsequent employment experiences. More specifically, our research has the following aims:

(1) To understand how and why UK students make the decision to study at overseas institutions. In particular we explore: the factors/considerations that inform this decision; the social and familial context to the decision-making process; and the relationship between social class, gender and ethnicity and overseas study.

(2) To generate new knowledge about the experiences of overseas-educated graduates on completion of their studies. In particular we consider: how graduates assess the value of their overseas education; whether they experience any obvious advantages or disadvantages in the labour market; and whether mobility for education is indicative of mobility after education.

This paper discusses four of the key themes that have emerged from our research. First, though, we provide an overview of the policy context of international HE and the salience of the concept of ‘employability’ in guiding students’ thinking about overseas education. 


\section{The UK and international education: an overview of policy}

Over recent years, international education has come to assume an increasingly important place within UK higher education policy. In part, this reflects wider global trends. Indeed, according to the OECD's latest calculations, in 2005, over 2.87 million tertiary students were enrolled outside their country of citizenship, representing a five per cent increase in total foreign student intake reported from the previous year (OECD, 2007). Moreover, over the past three decades, the number of students enrolled outside their country of citizenship has grown dramatically, from 0.61 million in 1975 to 2.73 million in 2005, closely linked to the increasing globalisation of economies and societies (OECD, 2007: 302). The UK's international outlook has also been influenced by more regional trends and, specifically, the Bologna Declaration (1999), which aims to create a European higher education area by 2010. This is a voluntary international agreement, driven largely by EU interests, which now includes 46 signatories. It seeks to make European higher education intelligible as a single system through: compatible degree structures to enhance student mobility between countries; the alignment of national quality assurance systems; a credit transfer system; and a common way of describing qualifications.

Over the last eight years, the British government's position on international education has found formal expression through two specific initiatives. The 'Prime Minister's Initiative on International Education' ran from 1999-2004 with the aim of increasing the number of nonEU international students in the UK by 75,000 by 2005 (achieved ahead of schedule), and encouraging collaboration between universities, colleges, government and other bodies to promote UK education abroad. This was followed by a second such initiative (commonly

referred to as 'PMI2'), which was launched in 2006 and will run until 2011. Although this is also motivated by a strong desire to increase the number of international students coming to 
the UK and secure the UK's place as 'a leader of international education', more importance has come to be placed on reciprocity between countries and institutions, acknowledging that British students and HE staff can themselves benefit significantly from the opportunity to study and/or work abroad. This shift in emphasis is evident in Tony Blair's speech in April 2006 (DfES, 2006), when he launched the second phase of his initiative, and also in the work that has been commissioned subsequently. This has included a good practice guide on student mobility (CIHE, 2007) intended to help higher education institutions prepare for greater outward mobility by their students. Explicit in this work is a recognition that a period of study abroad can offer important benefits to both the individual and wider society through the acquisition of a more cosmopolitan outlook and the development of inter-cultural skills.

While the UK has been one of the main recipients of international students over recent decades, British young people have tended to be quite reluctant to study abroad for the whole or part of their higher education. Although the UK has higher rates of outward mobility than other Anglophone countries such as the United States and Australia, it sends considerably fewer students abroad than most other EU countries (OECD, 2007; Sussex Centre for Migration Research, 2004). Nevertheless, there is some (largely anecdotal) evidence to suggest that interest in overseas study may be growing. For example, the Fulbright Commission has reported a sharp increase in interest from UK schools about undergraduate study in American colleges. Indeed, it reports that the number of schools to which it was invited to talk about studying in the US rose from 78 in 2004-05 to 159 in 2005-06 (Shepherd, 2006), while Harvard University, alone, received 275 applications from UK students in 2005. Reports have suggested that increasing interest in pursuing the whole of an undergraduate or postgraduate degree abroad may be driven, at least to some extent, by the introduction of top-up fees in the UK, which has made countries that charge very low fees or no fees at all (such as Sweden and the Netherlands) and those that offer significant financial 
aid (such as the US) more attractive in comparison (Clark, 2006). It is also the case that UK students are now being targeted more vigorously by overseas universities. For example, in 2006 Harvard began outreach work amongst state schools in the UK, to increase awareness of its policy of waiving fees for students from low income families. Our research intends to build on this evidence by exploring, in a more systematic manner, the reasons why UK students do become interested in studying overseas for the whole of an undergraduate or postgraduate degree.

\section{Employability and overseas study}

The project is also informed by wider debates about graduate employability. While a decision to pursue an undergraduate or postgraduate degree abroad may be prompted by changes to student finance in the UK, there is also some evidence to suggest that it may be underpinned by broader concerns about securing advantage within a congested graduate labour market.

Expansion of higher education in the UK, as in many other countries of the world, has been justified largely on economic grounds: that the UK must produce more highly skilled 'knowledge workers' if it is to compete effectively within the global economy. This is articulated clearly in recent government pronouncements on higher education and underpins the aim of expanding the sector to include 50 per cent of all under-30 year-olds by 2010 (DfES, 2003). Although some researchers have argued that expansion has generally been to the benefit of graduates and has led to the creation of a wide range of new graduate jobs (Purcell and Elias, 2004), not all have shared this positive analysis. Indeed, many scholars have argued that the number of highly skilled positions available in contemporary Britain has been overstated (Brown and Lauder, 2006), while others have shown that even young people - prime targets of government rhetoric in this area - are sceptical of many of the claims made 
about the nature of the 'knowledge economy' (Brooks and Everett, 2009). There is also growing evidence to suggest that there is now no automatic correspondence between academic credentials and labour market position. Indeed, both the normalisation of postcompulsory education and the expansion of higher education have tended to promote ‘credential inflation’ (Wolf, 2002).

Within this shifting educational landscape, it has been argued that privileged groups in society have to find new ways of securing their position relative to other groups; no longer are they able to rely on their dominance of the upper stages of the education process and an automatic transition into well-paid, professional employment. The literature outlines four main ways in which the middle classes have gone about trying to reproduce their social advantage. Firstly, Brown (1997) has argued that the last decade has witnessed the rise of a 'parentocracy' as parents become more closely involved in the education process to ensure that their children derive maximum advantage from their time at school and college and make the 'right' decisions about their educational futures. Such practices include detailed monitoring of schoolwork and ensuring that one's child benefits from schemes available to 'high-achieving' pupils (such as the 'Gifted and Talented’ programme) (e.g. Reay, 1992; Ball, 2002). Secondly, for (upper) middle class families, increasing importance has come to be attached to the status of the university their children attend, partly as a means of trying to secure maximum advantage within the labour market on graduation (Reay et al., 2005). However, Brown and Hesketh’s (2004) work on the practices of graduate employers demonstrates that even those with a good degree from a prestigious university are not guaranteed high status graduate employment. Thus, many students (and their families) have come to recognise the importance of gaining relevant experience - through paid work as well as extra-curricular activities - during one’s degree, to gain advantage over others who 
graduate with 'only' their academic qualification (Brooks, 2006). Finally, researchers have pointed to the role of further learning as part of wider strategies to secure positional advantage, whether this be through a postgraduate qualification (Bowl, 2003; Duke, 1994) or other forms of education or training (Brooks and Everett, 2008). In developing this analysis, we consider whether distinction from other graduates is also sought through overseas study.

The specific distinction wrought by an overseas education, however, is more difficult to qualify. In relation to East Asian students seeking education in the West, it has been found that 'overseas-educated' graduates are explicitly preferred by employers within service sector industries, over their 'locally-educated' counterparts (Waters, 2006). The reasons for this are said to include the enhanced English-language ability, broader communication skills, 'Western’ comportment, and cosmopolitan attitudes (including openness and creativity) found amongst 'overseas educated' graduates in East Asia (Waters, 2006). What is less clear, and what we explore in our work, is the perceived advantages that 'Western' students accrue from an overseas education. Is there any sense in which UK students are aware of a global market for skills, particularly in 'knowledge-based' professions (Brown and Hesketh, 2004), and have sought an overseas education in direct relation to this? We examine international education set against this background of credential inflation and a global knowledge economy, and ask, to what extent does going overseas for education provide students and graduates with a greater competitive edge in a UK (and potentially global) labour market?

\section{Research Methodology}

To explore these issues, we conducted 85 in-depth, qualitative individual interviews with UK students and graduates between September 2007 and February 2008. This method allowed us to explore respondents' own understandings and interpretations of events and processes. The 
interviews were guided by broad 'topic areas', but remained flexible, allowing respondents to raise any pertinent issues of their own.

The factors underpinning student choice and decision-making about international education, were investigated through individual interviews with 40 students who were seriously considering going overseas for HE study. We anticipated that choices may be configured differently for participants intending to study at undergraduate and postgraduate level, and therefore included equal numbers of both in the sample (20 sixth-formers and 20 undergraduates). Participants in this category were recruited through:

- Contact with 114 schools, by telephone, letter and email, located in Surrey, Greater Manchester, Merseyside and Cumbria. A mixture of state and independent schools was included in this sample.

- Contact with seven Connexions Head Offices in Greater Manchester, Merseyside, Cumbria, Staffordshire, Cheshire, Lancashire and West Yorkshire.

- The Fulbright Commission, which held a higher education fair to promote overseas study and allowed us to recruit sixth-formers.

- Advertisements posted on the announcement pages of Liverpool, Surrey and Leeds universities looking for students thinking of studying overseas at postgraduate level. 
- The creation of a Facebook group, inviting participants, whilst also participating in other Facebook groups.

Our second major research question addresses graduates’ experiences of studying overseas and the perceived impact of this on graduate labour-market outcomes. To explore such experiences, we conducted individual interviews with 45 young UK graduates who completed their overseas degree on or after the year 2000. We recruited participants in this category through:

- Alumni Associations - we contacted 65 associations with varying levels of success. We received significant help from Uppsala, Queensland, Rhodes and the Australian National University, in particular.

- The Canadian Rhodes Scholars Foundation, which sent out individual letters to all of their past UK scholars, and we received several participants by this route.

- The Commonwealth Scholars Commission, which publishes a directory of past scholars including their nationality and email addresses, and we contacted several participants by this route.

- Advertisements circulated to staff at a number of universities.

- Our own personal contacts. 
Through these channels, we achieved a reasonably diverse sample. The subject spread was wide and included: geography, economics, psychology, politics, international relations, literature, Viking studies, zoology, mathematics, nuclear physics, engineering, journalism, shark behaviour and education. Figures 1 and 2 show the locations of the institutions that our respondents had studied at or to which they were seriously considering applying. As they indicate, there was much less geographical diversity in relation to undergraduate study than for postgraduate: for the former group, high status universities in the US were by far the most common destinations (this is discussed in more detail below). In contrast, at postgraduate level, many more respondents had studied at or were intending to apply for courses at institutions outside the US. However, across the sample as a whole there were only four respondents who either had or were planning to study in a foreign language.

The characteristics of the respondents also differed considerably by level of education: the vast majority of those seeking/with an undergraduate overseas degree came from high socio- 
Figure 1. Spatial distribution of undergraduate sample

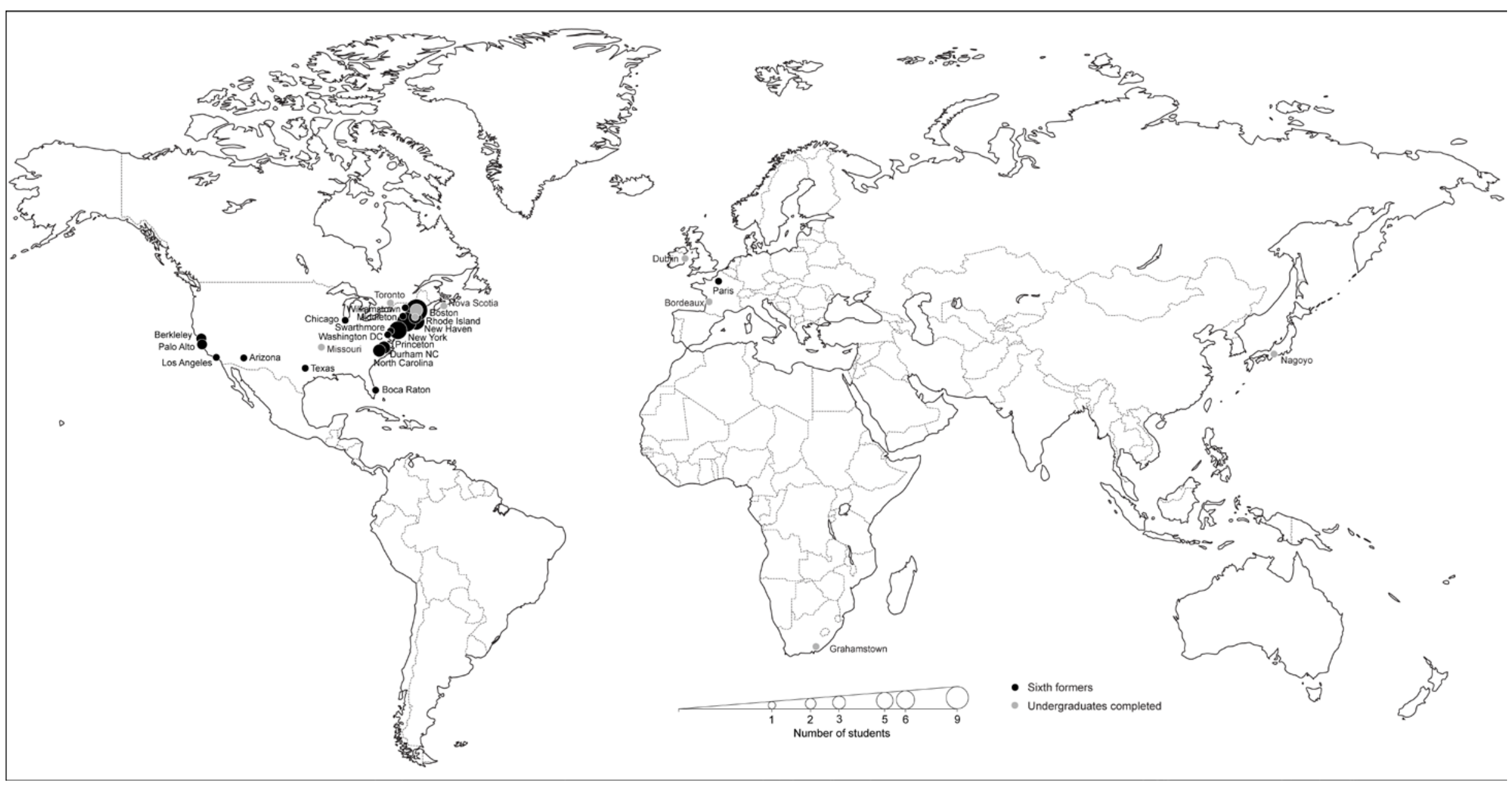


Figure 2. Spatial distribution of postgraduate sample

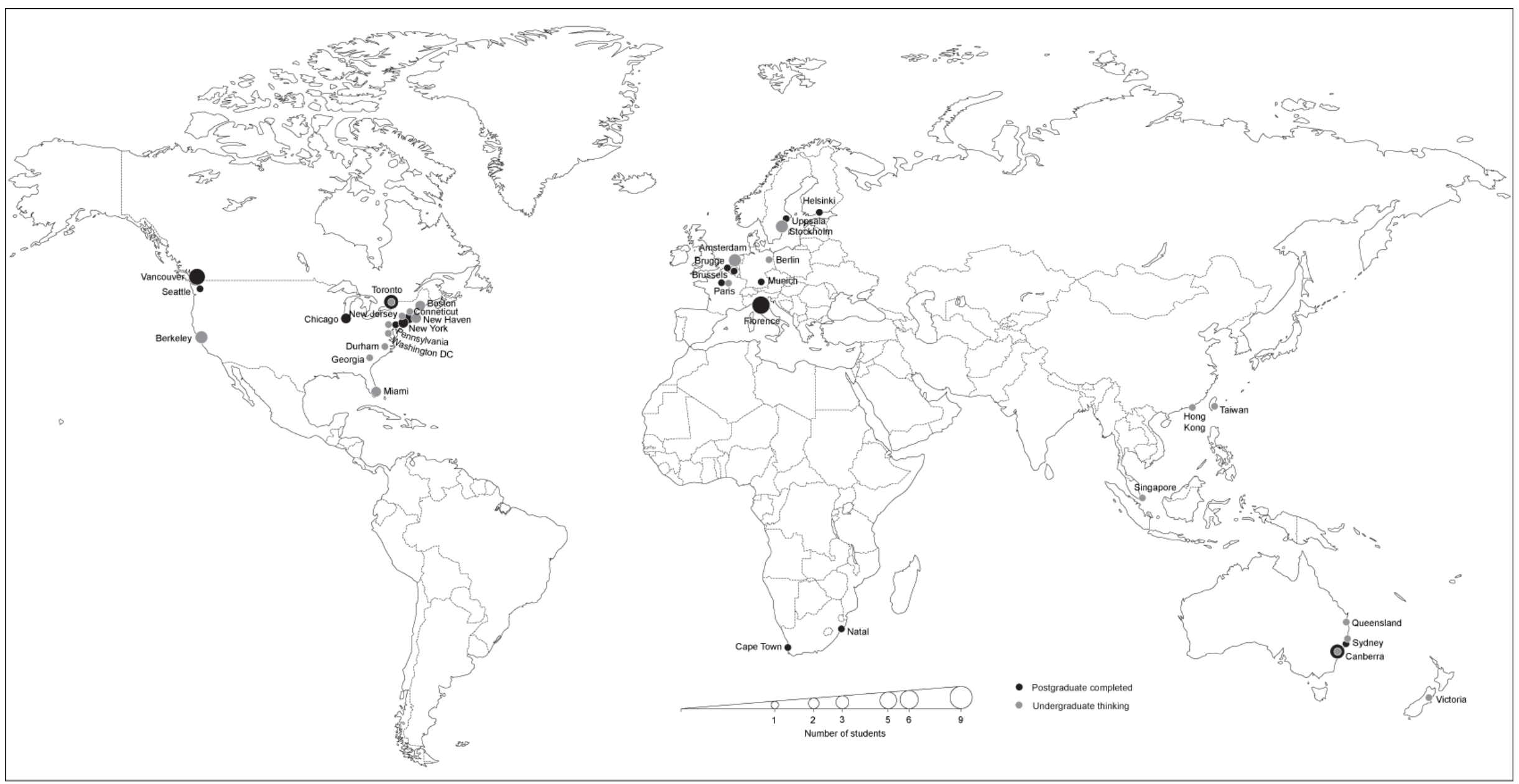


economic groups, had attended private secondary schools and had achieved high levels of academic attainment. We would suggest that this is not an artefact of our sampling method but rather a reasonably accurate reflection of the broader group of young people who pursue an undergraduate degree overseas. Our postgraduate sample was, however, much more diverse and included many from lower socio-economic groups and who had had more varied educational histories, including two who had studied for their first degree as mature students, and some who had 'dropped out' of education for a while.

\section{Emergent themes}

In what follows, we provide an overview of some of our findings in relation to four key themes: overseas education as a 'second chance'; the dominance of global 'circuits' of education; experiences of travel (before and after an overseas education); and labour market outcomes.

\section{(i) Overseas education as a 'second chance'}

In extant discussions of international education, the UK is almost invariably described as an attractive destination country for foreign students seeking an internationally renowned English-medium education system. Why, then, do some UK students decide to pursue their own education elsewhere? This is one of the key questions framing our research. One reason to have emerged from our data, which cuts across all categories of participants, concerns the opportunities that overseas study can provide for a second chance at 'success'. One participant, Jessica provides an excellent example of this. As a sixth former, her heart was set on studying chemistry at the University of Oxford, but her application to that institution was rejected. Rather than accept a place at one of the other universities that made her an offer 
(Durham, Imperial, Manchester, Nottingham and University College London), she decided to take a gap-year and re-apply to Oxford the following year. It was during her gap-year that she became interested in overseas study, as she was perusing the international league tables. She began to see study in the US (at very particular institutions, namely Harvard, Princeton or Yale) as offering an acceptable alternative to Oxford should she fail to win a place for the second time. She is only, she said, considering those US institutions that are "globally recognised and acknowledged”. A number of participants similarly perceived education overseas as a way of avoiding ‘failure' (or potential failure) ‘at home’. Another sixth form participant, Oliver, was interested in applying to Oxbridge but became concerned that "it’s really hard to get there” and so had settled on an overseas alternative, claiming that: "That's another thing about it: apparently there are more places in American universities, so it’s easier to get [in] there”. Like Jessica, he was thinking only of the 'top' US institutions (again Harvard, Princeton and Yale) as these were perceived to offer an acceptable alternative to Oxbridge.

These findings are interesting as they demonstrate what Bourdieu (1996) identified in a different context when he examined the emergence of new institutes of management in France. He wrote: '[the institute] provides a second chance, as it were, to students who have not received from the academic world the recognition they had been anticipating ...' (p. 217). He goes on to describe these institutes as 'honourable substitutes' for the most prestigious qualifications. This is what we have found in relation to international education - that in several cases it has provided an honourable substitute for Oxbridge for high achieving, high aspiring students. These students reported that their parents and other family members had 'expected’ that they might have attended an Oxbridge institution. These findings also go against prevalent social science discourses around international education and the desirability 
of 'mobility', which is seen as inherently valuable, more prestigious and preferred to a 'home’ experience (Huang and Yeoh, 2005; Morano-Foadi, 2005; Ong, 1999; cf. Waters, 2006) - not 'second best' as we have shown.

We have observed that this notion of a 'second chance' relates also to funding. Several of our participants noted that it was "easier” for them to secure funding for a postgraduate degree overseas than in the UK. One participant, Helen, had tried and failed to secure ESRC funding for a $\mathrm{PhD}$ in the UK whilst she had found it relatively simple to acquire EU funding for a $\mathrm{PhD}$ at an Italian institution.

\section{(ii) Global 'circuits' of education}

Research within the compulsory sector has shown that, within a market-driven system, different 'circuits' of schools emerge, which intersect, in quite complex ways, with social class and cultural capital. For example, in their work in Greater London, Ball and colleagues (1997) identify three main circuits of school (local, community, comprehensives schools; cosmopolitan, elite maintained schools; and local independent schools) and argue that different class fractions tend to choose within one circuit only. They go on to suggest that spatial factors are important, with different classes having different abilities to overcome what Harvey (1989) has called 'the friction of distance'. Similar arguments have been made in relation to the higher education sector within the UK. Indeed, Reay et al. (2005) have contended that while privately educated students identify primarily with elite universities such as Oxford and Cambridge, middle class state-educated students identify with pre-92 redbrick institutions and those from working class backgrounds feel most at home in new universities. Furthermore, data on university admissions have emphasised the different geographies of HE choice, with high achievers from more privileged backgrounds choosing 
within national markets of high status HEIs, while their peers engage within regional markets of less prestigious institutions.

Findings from our research extend this work by suggesting that a minority of highly privileged young people are making their HE decisions within global rather than national or regional circuits. As noted above, several young people considered that only an Ivy League university (such as Harvard, Yale or Princeton) would be good enough if they failed to gain a place at Oxbridge. Indeed, Linda explained that this was not a particularly unusual strategy at her school:

I think there were about, from my school, say five who went this year to America. A lot more apply and then don’t, often don't take their place if they get into Oxford or Oxbridge; they often do that. Like if I don't get into Oxbridge, then I'd like to go to America.

Similarly, when discussing his decision to apply to various highly-ranked American universities, Darren revealed that:

I’m going to wait and hear from Oxford. Depending on what Oxford say I'll decide whether or not I'll apply there....And so if I don't [get into Oxford] then I'll probably apply to Harvard.

Status issues were also referred to in relation to decisions about postgraduate study. Fergus, for example, explained how it had been important to him to attend a prestigious university in Australia, as anything else would be a 'step down' from Bristol University (where he had 
studied as an undergraduate). This was also a view held by his parents who, he believed, would have been reluctant to continue funding him if had not moved to an institution of equal or higher standing than Bristol. Moreover, even amongst those who did not refer explicitly to the importance of university status in their interview, there were strong implicit assumptions that they would be moving amongst only highly regarded institutions. Indeed, a large majority of the sample moved between institutions to be found in the top 100 of the World University Rankings (THES, 2007). Fourteen of our 34 respondents who had completed a postgraduate degree abroad had studied at Oxbridge before moving abroad, and several of them spoke of the strong informal links between their Oxbridge tutors and/or friends and the overseas institutions to which they moved. Edgar, for example, studied at Oxford as an undergraduate and used his college's links to secure a place at the University of British Columbia to pursue a master's degree. Thus, it appears that while the majority of the young people in our sample had little concern about the 'friction of distance' in making their decisions about university study, they were, nevertheless, choosing within a fairly limited 'circuit' of institutions (albeit a global one). Even a failure to secure a place at one elite institution did not lead to a shift 'downwards' to less prestigious circuits, but merely a movement 'sidewards' to a similarly-ranked institution in another country.

\section{(iii) Experiences of travel}

Through our research we sought to examine a potential, positive relationship between the tendency to seek an overseas education and subsequent mobility (following the completion of studies). Underpinning this was a number of assumptions: first, that the experience of overseas education would, amongst other things, cultivate a 'cosmopolitan' sensibility (Hannerz, 1996) amongst our sample, both instilling in them the desire to continue with travel 
and providing them with the cultural 'tools' necessary to do so. Second, that graduates would be more likely to seek out job opportunities that involved a degree of international mobility (particularly to the place of study), reflecting in part a desire for further travel whilst also revealing individuals’ perceptions of personal labour market or 'positional' advantage (Brown and Hesketh, 2004). Third, and linked to this second point, employers may be more likely to place 'overseas educated' graduates in roles requiring some form of international travel or engagement than their 'locally educated' counterparts, perceiving their experience of education as a form of 'cultural capital' (Bourdieu, 1986) that could be beneficial in a globally-orientated work environment.

The interview data reveal several dimensions - some unanticipated - to the relationship between an overseas education and travel. One significant finding was the overwhelming association between travel as a child or young adult and the tendency to seek out an international education. The vast majority of our sample, regardless of specific socioeconomic background, had extensive experience of travel when younger, often led by their parents, but sometimes independently or with friends. Travel had instilled in them a desire to explore and actively to seek out alternative experiences, much like the 'cosmopolitan' in Hannerz’s (1996) account. Several participants had family members who lived overseas (predominately in the US but some more widely spread) and travel as a child was often closely linked to familial visits. Overseas family members gave some the 'idea' of studying abroad. In one example, Joel describes how his family members in Canada had actively suggested the possibility. At the time, he was considering going either to Canada or to the US for a Master's degree. He had spent a lot of time in the US as a child visiting family on his 
mother's side. At one point he was thinking more specifically about applying to the University of Toronto. When asked what got him interested in that institution he said:

Before I went to university I was in Canada and I saw the university and I was quite accustomed to the, I just liked the kind of area itself, I just loved the country and the university looked great as well, in the city centre, and it just looked great. Was that for a holiday...?

Yeah, I was staying again - I’ve got family in Canada, so I stayed with them. But, yeah, it was really just a family visit, holiday type of thing.

His family spoke very highly of the University of Toronto, telling him that it was the best HE institution in Canada. In this way, extended family living overseas has had a notable and often direct influence on the decision making of UK students around higher education choices. More generally, it was apparent that a strong relationship exists between travel as a child and the desire to return to that location for study.

Not unrelated to this, several of our participants had a taken a 'gap year' between studying for their A levels and university. For the postgraduates, the opportunity for a 'placement' or 'year abroad' during undergraduate study at a UK institution would also seem to be very influential in the subsequent decision to study overseas, giving them a 'taste' for an overseas lifestyle. 
With regards to the question of whether travel for education could be seen as indicative of travel after education, we found little evidence of subsequent travel, amongst graduates, through (UK-based) work. Instead, far more unexpected was the apparently widespread tendency for these individuals to seek employment and often permanent relocation overseas. This finding, linking overseas education to emigration, went against our expectation that an overseas education would confer positional advantage in the $U K$ graduate labour market. It similarly contrasts with other research findings, which suggest that international academic credentials are most valuable 'back home’ where they are most scarce (Waters, 2006).

Overseas education and residency abroad were linked, in our data, in two main ways. In the first instance, individuals had made the decision to stay on at, or return shortly after to, the overseas location, directly reflecting their very positive experiences of studying there. Whilst studying, they had 'fallen in love' with a different lifestyle or culture. Lily, for example, had originally wanted to study in the US but had chosen Canada because it was cheaper - she said: 'and I figured Canada is practically the US, I'll go there!' She is now in the process of applying for permanent residency in Canada, and had chosen to do a second degree in Canada after making the decision to stay permanently. She said: 'I feel like it's my home now [...] I want to get settled, I want to stay where I am. I love this city [Toronto], I want to put some roots down.' For others with more long-term objectives, studying was seen as a route to living abroad - a way of getting a foot in the door by obtaining locally recognised credentials that would facilitate job seeking down the line as they sought permanent settlement. One participant, for example, said that having a degree from Australia 'allowed me to stay in Australia - it's a simple as that...[it] ticked a lot of boxes for me for other things like 
immigration and job prospects'. He had known before making the decision to study in Australia that he wanted to move there permanently, desiring a much more relaxed lifestyle.

\section{(iv) Labour market outcomes}

As noted above, we were keen to explore the impact of an expanding UK HE sector on the decision-making processes of our respondents and, in particular, whether an overseas education was perceived as a means of distinguishing oneself from the increasing number of labour market entrants in possession of a first degree. Contrary to our expectations, across the sample as a whole, there was very little evidence of study abroad being seen as a means of securing labour market advantage. While a considerable number of our postgraduate respondents had been motivated to enrol on master's or doctoral study to distinguish themselves from peers with only an undergraduate degree, an overseas education per se was not believed to offer the same kind of distinction. Indeed, their assessment of the benefits of further education and training strongly resemble those of graduates in other studies (Brooks and Everett, 2008; Bowman, 2005).

Moreover, when respondents who had completed an undergraduate or postgraduate degree abroad were asked to reflect on their subsequent labour market advantages, it became clear that a number had encountered some difficulties as a result of their overseas qualifications. Indeed, several of the postgraduate sample believed that they had been somewhat disadvantaged, at an early stage in their career, by the longer duration of their qualification, when compared to its equivalent in the UK. Others contended that many British employers knew little about overseas universities and, as such, were unsure about the value of a degree from an institution outside the UK. For example, when describing his difficulties in finding 
an appropriate job, Leo (who had studied at a prestigious grande école in Paris) conceded that, 'I suppose it's a bit frustrating that more people hadn't heard of where I'd studied'. Similarly, Doug believed that his PhD from the European University Institute carried much more weight in continental Europe than the UK:

\begin{abstract}
a little bit of a feeling I have....is that the European sort of continental European universities are working together quite a lot and I think the British are much more looking to the US or and that's it and ....And with the European universities - easy, much easier, they're much more, so I think in a way getting a job, if I was looking for work in other institutions it might easier in sort of continental Europe than it might be in the UK.
\end{abstract}

Furthermore, even Michelle, who was unusual within the sample for having thought initially that her overseas education would be likely to offer her an advantage over other graduates, came to the conclusion after several unsuccessful attempts to secure a job that 'people aren't massively interested' in her degree from Australia and went on to acknowledge that 'I think I was very disillusioned about how positive it was going to be for my future'. This provides a marked contrast to student mobility in other parts of the world where an overseas education is both highly regarded and constitutes valuable labour market currency within students’ countries of origin (Waters, 2006).

However, while an overseas education was not considered to offer any automatic advantage within the UK labour market, it was nevertheless believed to be very important in opening up work opportunities in the country of study. Indeed, for a considerable number of our 
respondents, this had been one of the most important reasons for pursuing an overseas education. As noted above, for many of these young people, this was inextricably linked to a wider desire to live and, in some cases, gain permanent residency within another country. For example, when asked about his motivation to study for an MA in Germany, Cecil explained how it was underpinned by his desire to live and work live in the country:

I knew I needed something else under my belt to go to a German employer...[if you] say right, I’ve got a BA from England in a non-business subject, you know you can expect your CV to go in the bin more or less straight away, it's too difficult for them to deal with. And I knew I needed something from Germany so I could prove look I'm capable of working in German, I'm capable of understanding business subjects in German and the idea was then OK well let's do this MA, let's do it part-time, let's teach English alongside that so I can earn enough money to survive and then once the MA is done, let's go out and try finding the dream job in Germany.

Similarly, when discussing his reasons for wanting to study for an undergraduate degree in the US, Oliver outlined similar motives:

It's kind of, ..... to be a lawyer in the USA and to do that you have to study US law....That's the way it came about.

Thus, while Ong (1999) has argued that globalisation has made economic calculation a major element in decisions about citizenship (i.e. that assessments about work opportunities often drive decisions about where to settle), for many of our respondents causality seemed to work 
in the opposite direction: securing employment overseas was seen as an important first step towards acquiring citizenship in a desirable country, and higher education played a facilitating role in opening up jobs that would, it was believed, remain closed to those holding only a British degree.

\section{Conclusion}

In conclusion, our research findings generally point towards the privileged nature of overseas study amongst UK students, particularly at undergraduate level. Those seeking undergraduate study abroad had, on the whole, highly supportive families with solidly middle-class backgrounds. They saw higher education as a natural and inevitable progression from school and had high aspirations with regards to their own educational achievement. Our postgraduate sample was more socially diverse, with less direct family guidance and input and more independence of mind apparent. For some of this sample, overseas study was a struggle and entailed some form of sacrifice. It was often perceived as a 'life-experience', as opposed to a strategy with specific employment and career objectives in mind. More specifically, in this paper we have identified four broad themes in relation to our empirical findings. Firstly, overseas study can be seen to offer a 'second chance' of success for students who failed to get into their preferred undergraduate institution, particularly those perceiving no 'acceptable' alternative to Oxbridge within the UK system. Leaving the system (moving 'sideways') to attend a highly ranked institution overseas is one way in which they can be seen to maintain their high level of achievement. An overseas education can also, as other examples show, offer opportunities for postgraduate funding, in particular, where none was available in the UK. Secondly, we have observed the existence of global (as opposed to national) circuits of elite institutions, within which UK students can be seen to move. As figures 1 and 2 (above) suggest, and our data explicitly show, although ostensibly global in 
nature, UK students tended to consider a relatively narrow and circumscribed set of overseas institutions and locations - North America (Canada and the US) was, overwhelmingly, the preferred destination region of study for UK students, followed by Australasia. When European institutions were considered, they were selected partly on the fact that they offered tuition in English, and often because they were 'cheaper' than even a UK alternative. Our findings point to a distinctive, emergent geography of international higher education, wherein the most powerful and wealthy nations of the world continue to benefit, whilst regions outside this nexus (notably Africa and parts of Asia) could be seen to lose out. A third theme discussed in this paper points to the relationship between international education and travel both prior to and after the completion of study. It was found that the vast majority of our sample had had some experience of travel as children or young adults, whether on holidays, family visits or as part of a gap year prior to HE or a placement year during it. This experience had been in some way influential in their subsequent decision to go overseas for education. In terms of mobility after the completion of studies, the greatest evidence pointed to the fact that many within our sample had sought more or less permanent employment and residency overseas. We have also discussed UK graduates’ labour market experiences in relation to their 'international' credentials. Contrary to expectations, students had generally not actively sought an overseas education with specific 'employability' objectives in mind. Furthermore, very few reported that their overseas degree had brought them particular advantages in the labour market. On the contrary, some had found it to be a disadvantage. An overseas degree has however, in some cases, facilitated living and working abroad. 


\section{References}

Ball, S. (2002) Class Strategies and the Education Market: The Middle Classes and Social Advantage. London: Routledge.

Ball, S., R. Bowe and S. Gewirtz (1997) 'Circuits of Schooling: a sociological exploration of parental choice of school in social-class contexts', in A. Halsey, H. Lauder, P. Brown and A. S. Wells (eds) Education: Culture, Economy, Society, pp. 409 - 421. Oxford: Oxford Univeristy Press.

Bologna Declaration (1999) The European Higher Education Area: Joint Declaration of the European Ministers of Education Convened in Bologna. 19 June 1999.

Bourdieu, P. (1986) 'The forms of capital', in J. G. Richardson (ed) Handbook of Theory and Research for the Sociology of Education, pp 241 - 258. New York: Greenwood Press.

Bourdieu, P. (1996) The State Nobility: Elite Schools in the Field of Power. Stanford California: Stanford University Press.

Bowl, M. (2003) Non-Traditional Entrants to Higher Education. London: Trentham Books.

Bowman, H. (2005) 'It's a year and then that's me': master’s students' decision-making'. Journal of Further and Higher Education 29 (3): 233-249.

Brooks, R. (2006) 'Education and work in the lives of young adults'. International Journal of Lifelong Education (Special issue: Beyond the Learning Society) 25 (3): 271-289. 
Brooks, R. and G. Everett (2008) 'The impact of higher education on lifelong learning'. International Journal of Lifelong Education 27 (3): 239 - 254.

Brooks, R. and G. Everett (2009, forthcoming) 'Post-graduation reflections on the value of a degree’. British Educational Research Journal.

Brown, P. (1997) 'The 'Third Wave': education and the ideology of parentocracy', in A. Halsey, H. Lauder, P. Brown and A. S. Wells (eds) Education: Culture, Economy, Society, pp. 393 - 408. Oxford: Oxford Univeristy Press.

Brown, P. and A. Hesketh (2004) The Mismanagement of Talent: Employability and Jobs in the Knowledge Economy. Oxford: Oxford University Press.

Brown, P. and H. Lauder (2006) 'Globalisation, knowledge and the myth of the magnet economy’. Globalisation, Societies and Education 4 (1): 25-57.

Butcher, A. P. (2004) 'Educate, consolidate, immigrate: educational immigration in Auckland, New Zealand’. Asia Pacific Viewpoint 45: 255 - 278.

Clark, T. (2006) ‘A free lunch in Uppsala’. The Guardian, 24 October 2006.

Collins, F. L. (2006) 'Making Asian students, making students Asian: the racialisation of export education in Auckland, New Zealand’. Asia Pacific Viewpoint 47 (2): 217 - 234.

Council for Industry and Higher Education (CIHE) (2007) Global Horizons for UK Students. A guide for Universities Available at: http://www.ciheuk.com/docs/PUBS/0707GLOBAL.pdf (Accessed 12 November 2007). 
Department for Education and Skills (DfES) (2003) The Future of Higher Education (Norwich: The Stationery Office).

Department for Education and Skills (DfES) (2006) Prime Minister Launches Strategy to Make UK Leader in International Education. Press Notice 2006/0058, 18 April 2006.

Duke, C. (1994) 'Lifelong, post-experience, postgraduate - symphony or dichotomy?’ in S. Haslegrove (ed) The Student Experience. Buckingham: Open University Press and SRHE.

Findlay, A., R. King, A. Stam and E. Ruiz-Gelices (2006) 'Ever reluctant Europeans: the changing geographies of UK students studying and working abroad'. European Urban and Regional Studies 13 (4): 291 - 318.

Harvey, D. (1989) The Condition of Post Modernity. Oxford: Blackwell.

Huang, S. and B. Yeoh (2005) ‘Transnational families and their children’s education: China’s “study mothers” in Singapore’. Global Networks 5 (4): 379 - 400.

King, R. and E. Ruiz-Gelices (2003) 'International student migration and the European 'yearabroad': effects on European identity and subsequent migration behaviour'. International Journal of Population Geography 9 (3): 229 - 252.

Lewis, N. (2005) 'Code of practice for the pastoral care of international students: making a globalising industry in New Zealand Globalisation, Societies and Education’ 3 (1): 5 - 47.

Morano-Foadi, S. (2005) 'Scientific mobility, career progression, and excellence in the European Research Area’. International Migration 43 (5): 133 - 162. 
OECD (2007) Education at a Glance. OECD Publications.

Ong, A. (1999) Flexible Citizenship: the cultural logics of transnationality. Durham: Duke University Press.

Purcell, K. and P. Elias (2004) Seven Years On: Graduate Careers in a Changing Labour Market London. The Higher Education Careers Services Unit.

Reay, D. (1992) Class Work. London: UCL Press.

Reay, D., M. David and S. Ball (2005) Degrees of Choice: social class, race and gender in higher education. London: Trentham Books.

Shepherd, J. (2006) 'UK Students Drawn to US for Broad-Based Degrees’, Times Higher Education Supplement, 4 August 2006.

Sussex Centre for Migration Research (2004) International Student Mobility. University of Sussex.

Times Higher Education Supplement (2007) World University Rankings http://www.thes.co.uk/worldrankings/ (Accessed 21 /11/07).

Waters, J. L. (2005) 'Transnational family strategies and education in the contemporary Chinese diaspora’. Global Networks 5: 359 - 378.

Waters, J. L. (2006) 'Geographies of cultural capital: education, international migration and family strategies between Hong Kong and Canada’, Transactions of the Institute of British Geographers 31 (2): 179 - 192. 
Wolf, A. (2002) Does Education Matter? Myths about education and economic growth. London: Penguin. 